\title{
"SUWUNG": POLA PENYELESAIAN MASALAH KAUM SUFI SUKU JAWA DI KOTA MALANG
}

\author{
Ninik Setiyowati \\ Fakultas Pendidikan Psikologi \\ Universitas Negeri Malang \\ Villa Bukit Tidar, At Boulevard, C1-319, \\ Malang 65144, Indonesia \\ e-mail: ninik.setiyowati.fppsi@um.ac.id
}

\begin{abstract}
Suwung" is a Javanesse term that describes an empty condition which has no form and is abstract. It implies emptiness with nuances of perfect self-control and true self-awareness with regard to divinity. Suwung, to the Sufi, is a spiritual experience called peak experience. Maslow defined peak experience as a condition when a person is feeling out of him-/herself mentally (Davis, 2003). Through this Suwung concept, humans can consciously solve the problems faced in life more wisely. Subject for the present research was grouped into three categories: (1) Sufis who have not met the basic needs (2) Sufis who meet the basic needs with struggle, (3) Sufis who meet the basic needs easily. The method used is the snowball sampling. Triangulation by a significant other was used for validation. The research method was qualitative phenomenology and utilizes symbolic interactionist analysis. As for the procedure, researchers conducted in-depth interviews to find the saturation values. The results of this study shows that the three groups of subjects were able to receive a problem with how to free themselves and essentially accepted the Lord in any condition. Narimo and gratitude circumstances be the basis for solving all subjects. In addition to that equation, there are three distinct patterns of thinking of a group of research subjects in solving a problem. First, humans solve problems encountered with resignation. Second, they resolve the problem by way of compromising with the facts. Third, they resolve the problem through the search for meaning of life.
\end{abstract}

Keywords: Problem solving; Suwung; phenomenology; symbolic interactionist; Narimo; grateful.

\footnotetext{
Abstrak- "Suwung" merupakan istilah Jawa yang menggambarkan kondisi kosong, tidak mempunyai bentuk dan abstrak. Di dalamnya mengandung makna kekosongan yang bernuansa pengendalian diri yang sempurna dan kesadaran sejati akan diri yang berkaitan dengan ketuhanan. Suwung bagi kaum sufi merupakan sebuah pengalaman spiritual yang disebut peak experience. Peak experience menurut Maslow dijabarkan sebagai suatu kondisi saat seseorang secara mental merasa keluar dari dirinya sendiri (Davis, 2003). Melalui pemahaman Suwung ini, manusia dengan sadar dapat memecahkan masalah yang dihadapi
} 
dalam kehidupan secara lebih bijaksana. Subjek penelitian ini dibagi menjadi 3 kategori yaitu: (1) kelompok penganut paham sufi yang masih belum terpenuhinya kebutuhan dasar hidup, (2) kelompok penganut paham sufi yang memenuhi kebutuhan dasar hidup dengan perjuangan, (3) kelompok penganut paham sufi yang memenuhi kebutuhan dasar hidup dengan mudah. Metode yang dilakukan adalah snowball sampling. Sedangkan validitas dilakukan dengan metode triangulasi significant other. Metode penelitian ini adalah kualitatif fenomenologi dengan proses analisis data menggunakan interaksionis simbolik. Dalam prosesnya, peneliti melakukan wawancara mendalam sampai menemukan data jenuh. Hasil dari penelitian ini menunjukkan bahwa dari ketiga kelompok subjek mampu menerima suatu masalah dengan cara mengosongkan diri dan secara hakiki menerima Tuhan dalam kondisi apa pun. Keadaan Narimo dan syukur menjadi dasar penyelesaian masalah bagi seluruh subjek. Selain persamaan itu, ada tiga perbedaan pola berpikir dari kelompok subjek penelitian dalam memecahkan suatu masalah. Pertama, manusia memecahkan masalah yang dihadapi dengan kepasrahan. Kedua, menyelesaikan masalah dengan cara berkompromi dengan fakta. Ketiga, menyelesaikan masalah melalui pencarian makna akan hidup.

Kata Kunci: Penyelesaian masalah; Suwung; fenomenologi; interaksionis simbolik; Narimo; syukur.

\section{PENDAHULUAN}

\section{Budaya Jawa}

Konsep teosofi di Pulau Jawa merupakan paham dalam agama Jawa. Teos berarti Tuhan dan sofia berarti cinta. Teosofi adalah ilmu Ketuhanan, yang cinta kebijaksanaan (kesempurnaan). Teosofi Jawa lebih mengedepankan pencarian kesempurnaan hidup (Endraswara, 2002). Hal ini berbeda dengan pengertian asal kata teosofi sendiri yakni bahasa Yunani yang menyebut para penganutnya dengan istilah orang Sufi. Sementara dalam bahasa Arab dikenal kata tasawuf yang berasal dari beberapa istilah antara lain shifa, shuf, shuffah, dan shuffanah. Penganut tasawuf juga bergelar Sufis. Istilah-istilah tersebut berarti: (1) Shifa, artinya suci bersih, ibarat kilat kaca; (2) Shuf yang artinya bulu binatang. Sebab orang-orang yang memasuki tasawuf ini memakai baju dari bulu binatang, mereka benci pakaian yang indah-indah atau pakaian "orang dunia"; (3) Shuffah yaitu segolongan sahabat nabi yang menyisihkan dirinya di suatu tempat terpencil di samping Masjid Nabi; dan (4) Shuffanah yang artinya sebangsa kayu yang mersik tumbuh di padang pasir tanah Arab (Hamka, 2015).

Penelitian ini mengangkat konsep sufi yang secara spesifik ada pada masyarakat Jawa, yang tidak lepas dari akar bahasanya baik dari pengertian Yunani maupun Arab. Peneliti merumuskan pengertian Sufi adalah suatu jalan atau proses yang ditempuh oleh seseorang untuk memahami dan mengimani 
Tuhan dengan sempurna, melalui perilaku (perbuatan) yang melepaskan diri dari keterkaitan dengan duniawi sehingga bisa mencapai kesucian diri yang sempurna.

\section{Konsep Suwung}

Tarekat adalah jalan yang harus ditempuh oleh setiap calon Sufi untuk mencapai tujuannya, yakni bersatu dengan Tuhannya. Pada jalan tersebut terdapat tahapan-tahapan yang harus dilalui, seperti: tobat, zuhud, sabar, ridho, mahabbah, dan ma'rifatullah (mengenal Allah dengan hati nurani). Bila mencapai tahapan ma'rifatullah, maka calon Sufi telah meningkat menjadi Sufi (Achmad, 2014). Jalan atau cara yang ditempuh oleh para calon Sufi ini memengaruhinya dalam bertindak, melakukan pengambilan keputusan maupun bagaimana ketika ia mendapati suatu permasalahan yang harus ditemukan solusinya.

Dalam Ajaran Suluk Sukma Lelana (Ronggo Warsito), pencapaian ma'rifatullah berlangsung dalam empat tahapan, yaitu (1) tahapan Syariat, (2) tahapan Tarekat, (3) tahapan Hakikat, (4) tahapan Ma'rifat. Tahap Ma'rifat merupakan bentuk capaian tertingginya, yaitu ketika manusia mengetahui tentang hakikat Ketuhanan. Dalam hal ini, manusia dianggap sebagai makhluk sempurna karena telah mampu mencapai puncak spiritual yakni "Manunggaling kawulo-Gusti”. Kesatuan kosmis yang di dalam masyarakat Jawa dilambangkan sebagai “curiga manjing warangka, warangka manjing curiga” (keris menyatu dengan kerangkanya, kerangka menyatu dengan kerisnya) (Achmad, 2014).

Melalui pengalaman kehidupan yang dialami, seseorang akhirnya bisa menembus dinding dan pembatas yang berada dalam ruang dan waktu yang bersifat fisik. Hakikat kehidupan ini tidak berada pada kepentingan-kepentingan duniawi yang sifatnya sementara. Kesadaran tertinggi ini yang menjadikan seseorang mampu mencapai “Alam Suwung” secara total. Dalam prosesnya, "keakuan" dapat dikontrol secara baik sehingga hidup dapat dihayati dengan menjauhkan diri dari kesombongan.

Dalam konsep spiritual dari Maslow, pengalaman spiritual tertinggi yang dicapai seseorang ini dinamakan peak experience. Pada mulanya, dasar intrinsik, esensi, inti universal dari setiap agama merupakan sesuatu pengalaman pribadi, sendiri, pencerahan personal, dan wahyu atau pencapaian puncak dari nabi atau para penglihat (Maslow, 1964). Namun, terlihat bahwa wahyu atau pencerahan yang bersifat mistik ini dapat digolongkan sebagai peak experience, ecstasies, atau trancendent.

Psikologi transpersonal meneliti berbagai konsep (Walsh \& Vaughan, dalam Davis, 2003). Beberapa konsep kunci adalah (1) peak experience, di dalamnya meliputi emosi positif yang kuat dan mendalam seperti ecstasies, perasaan damai dan ketenangan, perasaan senada dan selaras dengan alam, kesadaran mendalam yang tidak bisa diterjemahkan dengan kata-kata; (2) self-transcendence 
merupakan suatu keadaan kesadaran di mana perasaan diri berkembang di luar definisi biasa dan image atau gambaran diri dari suatu kepribadian individual. Self-transcendence meliputi pengalaman langsung dari hubungan fundamental, harmoni dan menyatu dengan alam; (3) optimal mental health berarti kemampuan coping yang mencukupi dengan tuntutan lingkungan dan merupakan resolusi dari konflik personal; (4) spiritual emergency, dalam konsep transpersonal adanya suatu krisis dalam diri seseorang dapat menjadi bagian yang membangkitkan kesehatan dan tidak selalu merupakan bentuk dari psikopatologi; (5) developmental spectrum, digambarkan membedakan antara tahapan pre-personal dari perkembangan diri, sebelum perkembangan perasaan stabil dalam diri, kemudian tahapan personal di mana perkembangan dan perbaikan individu telah berhasil diraih. Tahapan transpersonal didasarkan pada identifikasi dengan keseluruhan bahwa diri lebih tinggi daripada ego individual; (6) meditation, yang merupakan metode kunci dari psikologi transpersonal. Meditasi melibatkan fokus pada satu objek atau perhatian sadar pada seluruh aspek kesadaran (Davis, 2003).

Dalam konsep transpersonal, ketika seseorang menghadapi suatu masalah yang menempatkannya pada suatu krisis spiritual, hal tersebut justru akan menjadikan manusia mampu membangkitkan kondisi kesehatan mental yang sempurna. Hal tersebut terjadi apabila dapat diolah dan diinternalisasi ke dalam hakikat masalah tersebut.

Menurut konsep Rangga Warsito, dalam serat wirid hidayat jati tertuang konsep dasar sebagai berikut:

Sejatine ingsun anata malige ana sajroning betal muharram

Iku omah enggoning lalaranganing ingsun

Jumeneng ana dhadhaning adam

Kang ana sajroning dhadha itu ati

Kang ana sajroning ati iku jantung,

Sajronng jantung iku budi,

Sajroning budi iku jimen, iya iku angen angen

Sajroning angen angen iku rahsa,

Sajroning rahsa iku ingsun

Ora ana pangeran among ingsun dat kang angliputi jati

Berdasarkan para penganut Sufi di Jawa, ajaran Rangga Warsito adalah manifestasi tertulis yang dipergunakan oleh kaum Sufi dalam menjalani kehidupannya. Adapun hasil penelitian ini menterjemahkan kalimat di atas sebagai berikut: 
Sesungguhnya AKU merajai istana di dalam Betal Muharram. Tuhan yang merajai istana yang di dalamnya terdapat aturan-aturan dan larangan, yang terletak di dada Adam, di dalam dada ada hati, di antara hati ada jantung, di dalam jantung ada budi, di dalam budi ada jinem (yaitu harapan), di dalam harapan ada rahsa, di dalam rahsa ada Aku, tiada Tuhan kecuali Aku, Dzat yang meliputi keadaan hakiki.

Dari sudut pandang ini, dapat dilihat ada tahapan-tahapan yang perlu dilalui. Meskipun ternyata dari tahapan itu tidak selalu bersifat runut dan kontinu. Lompatan itu bisa dilakukan oleh orangorang tertentu apabila dia menghadapi permasalahan personal yang berhasil mengubah seluruh sudut pandangnya. Dari hasil penelitian untuk semua subjek memiliki pola pencapaian rasa Suwung yang sama tetapi tahapannya bervariasi sesuai dengan pengalaman hidup yang dialaminya masing-masing.

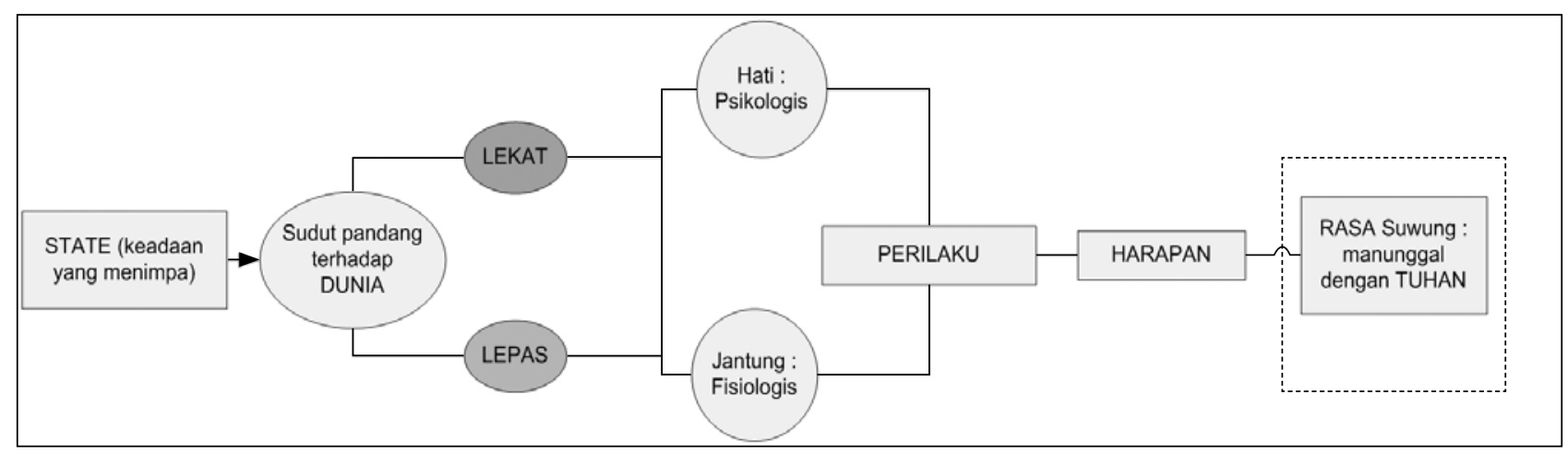

Bagan 1. Tahapan dalam Pencapaian Alam Suwung

Titik penting dari perjalanan menuju Suwung adalah kondisi awal ketika menghadapi kenyataan. Sudut pandang terhadap sisi dunia dibagi menjadi dua, yaitu: (1) Lekat, suatu kondisi diri seseorang, ketika memandang dunia penting untuk diperjuangkan, mengharapkan sesuatu yang dicita-citakan dapat dicapai dengan baik. Apabila mengalami kegagalan, maka akan mengoreksi diri untuk memperjuangkan kembali mimpi mimpinya; dan (2) Lepas, suatu kondisi diri seseorang, ketika memandang dunia akan hadir dan hilang dengan ritme yang harmonis. Menunaikan tugas sebagai manusia, memenuhi kebutuhannya namun tidak membelenggu diri dengan harapan akan tercapainya mimpi-mimpi. Hidupnya adalah sekarang dan di sini (right here, right now).

\section{Strategi Pemecahan Masalah}

Menurut Matlin (2005) strategi pemecahan masalah adalah ketika dinyatakan adanya suatu masalah, maka harus menyelesaikan masalah tersebut dengan menggunakan berbagai cara untuk 
mengatasi masalah tersebut. Beberapa strategi yang sering digunakan adalah: (1) Algoritma. Algoritma adalah metode yang selalu menghasilkan suatu solusi yang benar dari setiap penyelesaian masalah; dan (2) Heuristik. Menurut Matlin (2005) dalam pemecahan masalah, heuristik adalah suatu strategi yang mengabaikan beberapa penjelasan serta hanya menggunakan alternatif yang paling disukai untuk mendapatkan suatu solusi.

Menurut Matlin (2005), ada 3 heuristik yang paling sering digunakan yaitu: (1) heuristik hillclimbing, (2) heuristik means-ends, dan (3) pendekatan analogi.

Salah satu strategi pemecahan masalah yang paling mudah biasanya disebut dengan heuristik hill-climbing. Heuristik hill-climbing adalah ketika individu memiliki masalah, maka individu tersebut memilih solusi secara sederhana terhadap alternatif jawaban yang tampak untuk menyelesaikan masalah (Lovett, dalam Matlin, 2005). Heuristik hill-climbing dapat digunakan ketika individu tidak cukup menemukan informasi mengenai alternatif-alternatif solusi yang dipilih oleh individu tersebut (Dunbar, dalam Matlin, 2005). Heuristik hill-climbing digunakan oleh individu ketika: (1) Memilih solusi yang tampak secara cepat dan sederhana dari masalah yang dihadapi; dan (2) Apabila solusi pertama dianggap gagal, maka individu memilih solusi berikutnya dari masalah yang dihadapi

Menurut Matlin (2005), heuristik means-ends memiliki 2 komponen yaitu: (1) individu membagi masalah ke dalam sub-sub masalah atau ke dalam masalah yang lebih kecil; dan (2) individu mencoba untuk mengurangi perbedaan mengenai keadaan awal dengan kondisi tujuan terhadap masing-masing sub masalah. Heuristik means-ends tepat karena mengharuskan individu untuk mengidentifikasi tujuan yang diinginkan dan kemudian mencari tahu cara yang akan digunakan untuk mencapai tujuan-tujuan tersebut.

Sedangkan, menurut Matlin (2005), ketika individu menyelesaikan masalah dengan menggunakan pendekatan analogi, individu menggunakan solusi yang sama dengan masalah sebelumnya untuk menyelesaikan masalah yang baru. Adapun indikator individu menggunakan pendekatan analogi, antara lain: (1) individu menggunakan solusi yang sama atau serupa terhadap masalah serupa yang ia hadapi, dan (2) individu menggunakan solusi yang sama atau serupa ketika masalah yang ia hadapi sama atau serupa dengan masalah yang pernah dihadapi oleh orang lain.

Berdasarkan dari beberapa strategi pemecahan masalah yang dikemukakan di atas dapat disimpulkan bahwa strategi pemecahan masalah merupakan suatu teknik atau cara yang digunakan oleh individu untuk menemukan solusi dalam menyelesaikan masalahnya, antara lain dengan menggunakan teknik algoritma atau heuristik. 
Penelitian mengenai pemecahan masalah yang cukup terkenal adalah menghubungkan meditasi dengan peningkatan kemampuan pemecahan masalah. Penelitian ini menunjukkan adanya perbedaan kemampuan penyelesaian masalah lebih baik daripada sebelum adanya perlakuan meditasi (Ren, dkk., 2011). Adapun penelitian mengenai pemecahan masalah dari sudut pandang psikologi kognitif menekankan pada peran penalaran dan deduksi dalam pemecahan masalah dan proses yang terlibat dalam strategi pemecahan masalah dari yang paling tidak efektif sampai yang paling efektif (Lee \& Johnson-Laird, 2013).

Penelitian-penelitian yang muncul selama ini menekankan pada strategi pemecahan masalah, langkah-langkah dan metode yang efektif untuk pemecahan masalah tersebut. Dalam penelitian ini, yang menjadi poin utama adalah dinamika psikologis individu ketika menghadapi suatu masalah. Berdasarkan konsepnya, ketika secara psikologis seseorang telah menjadi Suwung, maka baik afektif, kognitif maupun psikomotornya akan lebih jernih ketika menghadapi suatu permasalahan.

\section{Masalah Penelitian}

Setiap manusia selalu dihadapkan pada persoalan hidup. Apabila seseorang gagal dalam pemecahan masalah, akan berdampak pada keberlangsungan hidupnya. Misalnya di tahun 2015 angka penyebab kematian terbesar polisi adalah akibat bunuh diri (Wibisono, 2015). Penyelesaian masalah yang mereka lakukan cenderung mengakhiri hidup tentu bukan hal yang positif dilakukan. Bahkan ketika ada masalah ekonomi yang membelit, masyarakat terbelenggu stres. Mereka mengalami gangguan mental emosional berupa stres, kecemasan, dan depresi yang tidak hanya terjadi di masyarakat kota, tapi juga di desa, kota kecil hingga pulau terluar pun banyak yang mengalaminya (Ire, 2015).

Penelitian ini menjadi relevan karena maraknya permasalahan psikologis yang mengarah pada kondisi tidak sehat muncul dari masyarakat karena respons individual terhadap pemecahan masalah kurang memadai. Dengan memahami konsep Suwung, diharapkan masyarakat yang mengalami permasalahan dalam hidupnya tidak menempuh cara-cara negatif untuk mengatasi masalahnya tersebut. Selama ini telah diketahui bahwa golongan sufi menunjukkan perilaku yang lebih bisa adaptif terhadap permasalahan hidup.

\section{Tujuan dan Pertanyaan Penelitian}

Kaum Sufi memiliki teknik atau cara yang unik untuk menemukan solusi dalam menyelesaikan masalahnya. Keunikan itu berkaitan erat dengan konsep hidup yang dianutnya. Penelitian ini bermaksud menemukan pola penyelesaian masalah (problem solving) bagi kaum Sufi yang menganut konsep Suwung. 


\section{METODE}

\section{Partisipan}

Menurut Maslow, untuk mencapai tahapan aktualisasi diri, manusia perlu untuk memenuhi kebutuhan dasar hidup. Oleh karenanya, penelitian ini dipisahkan menjadi tiga kelompok subjek penelitian; (1) kelompok penganut paham Sufi yang masih belum terpenuhinya kebutuhan dasar hidup, (2) kelompok penganut paham Sufi yang memenuhi kebutuhan dasar hidup dengan perjuangan, (3) kelompok penganut paham Sufi yang memenuhi kebutuhan dasar hidup dengan mudah. Metode pengambilan partisipan ini dengan melakukan wawancara awal pada dua tokoh masyarakat di kota Malang yang memahami konsep Suwung, sekaligus menjadi significant other bagi partisipan penelitian. satu tokoh masyarakat yang menjalankan syariat Islam secara Nahdlatul Ulama, dan satu tokoh masyarakat yang menjadi pemimpin Majelis Dzikir di kota Malang. Kriteria yang diajukan untuk didiskusikan dengan significant other adalah subjek dengan sikap hidup yang mencerminkan konsep Suwung.

\section{Desain}

Metode penelitian ini adalah kualitatif fenomenologi. Dalam prosesnya, peneliti melakukan wawancara mendalam sampai menemukan data jenuh. Wawancara dilakukan dua kali pada masingmasing subjek dari 16 Januari 2014 hingga 10 Mei 2014. Seluruh subjek adalah penduduk kota Malang. Tiga orang berafiliasi dengan 1 Toriqoh, 6 subjek meyakini konsep spiritual secara individu namun menjalankan syariat Islam secara Nahdlatul Ulama.

\section{Teknik Pengumpulan Data}

Untuk memperoleh validitas, dilakukan triangulasi significant other. Significant other merupakan orang yang sama yang menjadi informan awal penetapan subjek dan secara umum mengenal subjek lebih dari lima tahun dalam komunitas yang menjalankan paham Sufi.

Wawancara yang digunakan berbentuk wawancara tidak terstruktur. Pedoman wawancara yang digunakan meliputi tema sebagai berikut: (1) Awal mula menggunakan konsep Suwung, yang termasuk pengalaman yang menjadi titik balik dalam proses pencapaian rasa Suwung, perilaku yang mendukung dalam proses pencapaian rasa Suwung, harapan yang muncul dalam proses pencapaian rasa Suwung, dan perasaan tertinggi yang muncul ketika akhirnya memilih jalan Suwung; dan (2) proses penyelesaian masalah setelah pencapaian rasa Suwung, yang termasuk masalah yang dihadapi, perasaan ketika 
menghadapi masalah, perilaku yang muncul ketika menghadapi masalah, dan perasaan yang muncul ketika berproses dalam menyelesaikan masalah.

\section{Teknik Analisis}

Penelitian ini menggunakan metode interaksionis simbolik. Menurut Larossa dan Reitzes (dalam West-Turner, 2008), interaksi simbolik menjelaskan kerangka referensi untuk memahami bagaimana manusia, bersama dengan orang lain, menciptakan dunia simbolik dan bagaimana cara dunia membentuk perilaku manusia.

Interaksi simbolik ada karena ide-ide dasar dalam membentuk makna yang berasal dari pikiran manusia (mind) mengenai diri (self), dan hubungannya di tengah interaksi sosial. Tujuan dari semua hal di atas adalah untuk memediasi dan menginterpretasi makna dalam masyarakat (society) di mana individu berada. Douglas (dalam Ardianto, Elvinaro, \& Bambang, 2007) menyatakan bahwa makna itu berasal dari interaksi, dan tidak ada cara lain untuk membentuk makna selain dengan membangun hubungan dengan individu lain melalui interaksi.

Definisi dari ide dasar dari interaksi simbolik, antara lain: (1) pikiran (mind) adalah kemampuan untuk menggunakan simbol yang mempunyai makna sosial yang sama, di mana tiap individu harus mengembangkan pikiran mereka melalui interaksi dengan individu lain, (2) diri (self) adalah kemampuan untuk merefleksikan diri tiap individu dari penilaian sudut pandang atau pendapat orang lain, dan teori interaksionisme simbolis adalah salah satu cabang dalam teori sosiologi yang mengemukakan tentang diri sendiri (the-self) dan dunia luarnya, dan (3) masyarakat (society) adalah jejaring hubungan sosial yang diciptakan, dibangun, dan dikonstruksikan oleh tiap individu di tengah masyarakat, dan tiap individu tersebut terlibat dalam perilaku yang mereka pilih secara aktif dan sukarela, yang pada akhirnya mengantarkan manusia dalam proses pengambilan peran di tengah masyarakatnya.

"Mind, Self and Society" merupakan karya George Harbert Mead yang paling terkenal (dalam West-Turner, 2008), di mana dalam buku tersebut memfokuskan pada tiga tema konsep dan asumsi yang dibutuhkan untuk menyusun diskusi mengenai teori interaksi simbolik. Tiga tema konsep pemikiran Mead yang mendasari interaksi simbolik ini yang peneliti gunakan untuk memetakan subjek penelitian mengenai Suwung ini. Penekannya ada pada: (1) menemukan pentingnya makna bagi perilaku penganut sufi yang menggunakan konsep Suwung dalam penyelesaian masalah, (2) menemukan pentingnya konsep mengenai diri sendiri, bagaimana ia bersikap dan seluruh dinamikanya ketika menghadapi suatu masalah, dan (3) menemukan hubungan antara individu yang menganut paham sufis dengan konsep Suwung terhadap masyarakat sekitarnya khususnya ketika bertingkah laku dan menempatkan diri. 


\section{HASIL DAN ANALISIS}

Berikut adalah karakteristik dari partisipan yang terlibat dalam penelitian ini.

Tabel 1.

Kriteria Subjek

\begin{tabular}{lcccclll}
\hline & Usia/th & Pendidikan & Kelamin & $\begin{array}{l}\text { aktif } \\
\text { sufis }\end{array}$ & Pekerjaan & $\begin{array}{l}\text { Penghasilan/ } \\
\text { Bulan }\end{array}$ & Kode Subjek \\
\hline Subjek 1 & 56 & SD & L & 16 & Satpam & 700 Ribu & SS040515DD \\
Subjek 2 & 51 & SD & L & 5 & Buruh pabrik & 1.2juta & RR040515DI \\
Subjek 3 & 45 & MI & L & 6 & Petugas kebersihan & 1 juta & TT010516LL \\
Subjek 4 & 59 & S2 & L & 9 & Dosen & 5 juta & AA090515KK \\
Subjek 5 & 49 & S1 & L & 3 & Guru & 3.5 juta & AE100515KK \\
Subjek 6 & 45 & S1 & L & 5 & Pegawai swasta & 4 juta & AI110515KK \\
Subjek 7 & 45 & S1 & L & 5 & Pengusaha & 10-20 juta & KL090515SS \\
Subjek 8 & 53 & S1 & L & 4 & Pengusaha & 6-10 juta & KK080515MM \\
Subjek 9 & 54 & S1 & L & 14 & Pengusaha & 8-12 juta & JN090515SS \\
\hline
\end{tabular}

Dalam menghadapi permasalahan, partisipan yang menjadi subjek penelitian dibedakan berdasarkan sudut pandangnya terhadap dunia. Pengambilan data ini dilakukan dengan wawancara awal dengan pertanyaan: "Bagaimana anda memandang dunia dan seluruh isinya?" Dari sampel penelitian terbentuk model sesuai dengan bagan pencapaian alam Suwung, namun dengan beberapa kekhasan.

Dari model pencapaian alam Suwung, ditemukan pola-pola yang berbeda pada partisipan. Adapun model tersebut adalah sebagai berikut:

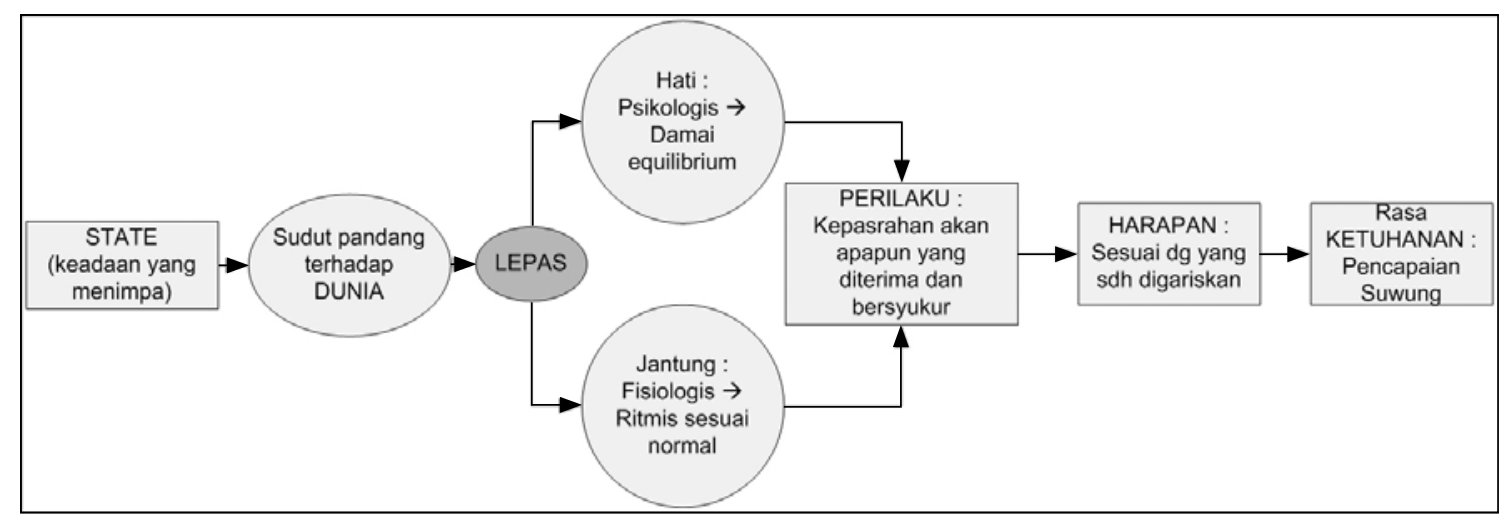

Bagan 2. Tipe 1 Pencapaian Alam Suwung 
Respons terhadap pertanyaan "bagaimana anda memandang dunia dan seluruh isinya?" adalah sebagai berikut.

"lahir mboten nyuwun, di lairne mboten saget nolak. Hanya wayang gusti Allah. Kados pundi maleh? Sampun manut, ikut apa yang sudah menjadi garis Gusti Allah" (SS040515DD).

"Titipan. Semua milik Allah. Hidup itu ibarat berjalan Cuma mampir ngombe. Nanti akan kembali. Apa yang diperjuangkan berlebihan tidak dibawa mati” (RR040515DI).

"Bagian dari pancaran cahaya Allah di semua ciptaan-NYA. Termasuk dunia ini. Ada Rabb di dalam diri kita. Pasti nanti akan kembali padanya. Dan memang itu tujuan kita. Dunia itu jalan yang harus dilalui saja. ujungnya kan bersatu dengan-NYA" (AA090515KK).

"Dunia... dunia ... apa.. ndak ada yang bisa dimaknai secara mendalam. Hanya memang kita perlu disini dulu. Nanti mati, ya lepas. Tidak ada ikatan apa-apa di dunia ini. Hanya tempat. Iya. Tempat sementara sebelum menuju alam selanjutnya yang lebih abadi“(AE100515KK).

"Tempat ngumpulin sangu akhirat. Jadi tempat untuk berbuat sebaik-baiknya. Bermanfaat buat sesama. Agar makin mendekatkan diri kepada Allah”(JN090515SS).

Tipe 1 diawali dengan paradigma berpikir bahwa dunia adalah upaya penunaian tugas yang diberikan Tuhan. Mereka yang ada pada tipe ini tidak melibatkan diri untuk memperjuangkan citacita, apalagi disertai ambisi untuk memperoleh hasil yang lebih baik dari orang lain. Ketika seseorang dihadapkan pada suatu persoalan yang sulit, maka mereka cenderung menunjukkan kepasrahan dan menerima dengan lapang dada, karena dunia hanya bagian kecil dari perjalanan panjang menuju Tuhan.

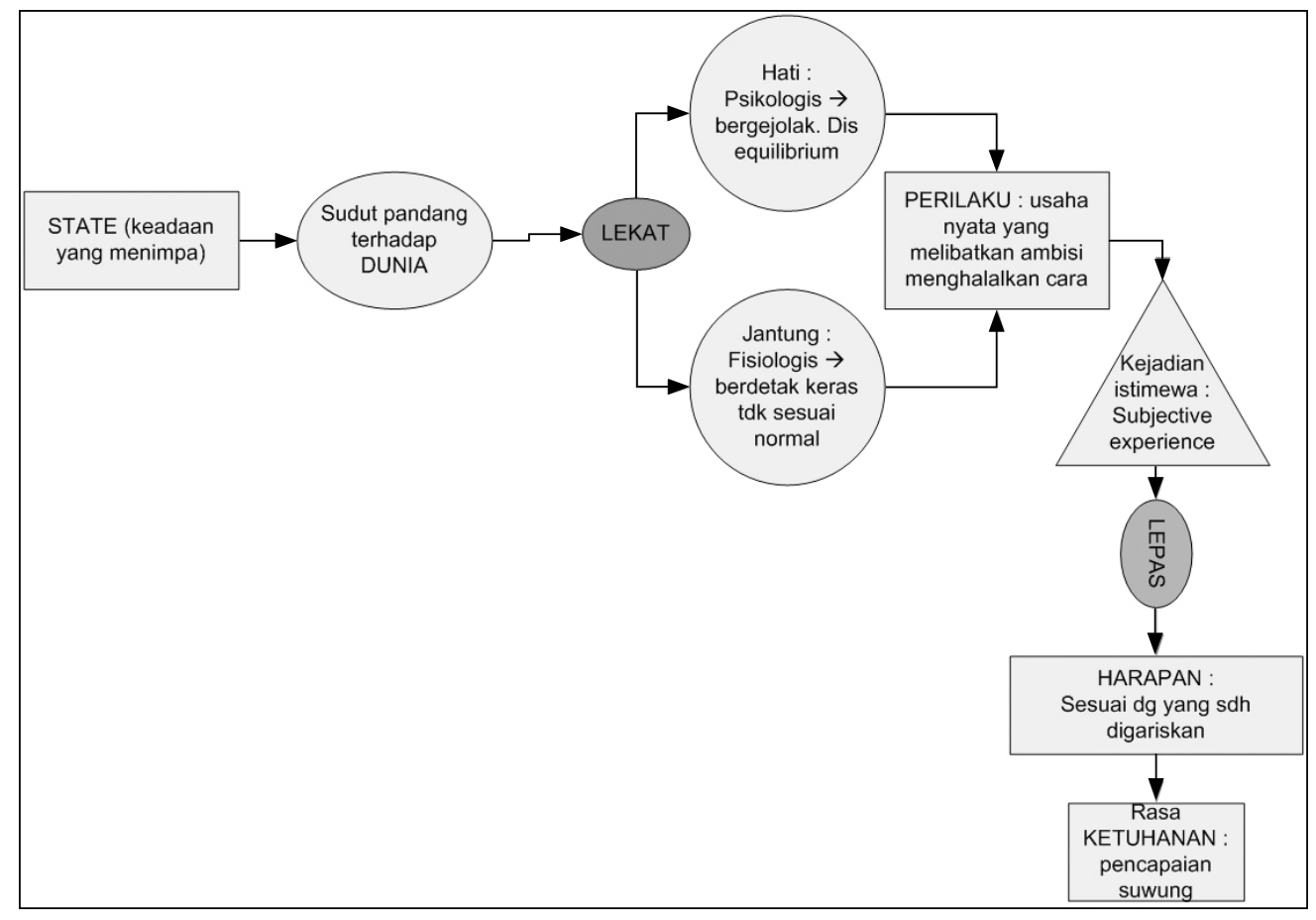

Bagan 3. Tipe 2 Pencapaian Alam Suwung 
Berikut adalah respons dari partisipan:

(1) "Dunia, tempat yang keras, butuh kekuatan untuk bertahan di sana. Saya sudah begini, anak saya kelak ndak boleh seperti ini. Minimal lebih baik.”. (2) “anak saya itu segalagalanya bagi saya. Takjaga koyo barang wadi. Ndak boleh kenapa-kenapa. Tapi sakitjuga. Meh meh bar mba. Gusti Allah sing duwe nyowo. Dijogo koyo opo kalo memang harus sakit sakit juga" (TT010516LL).

(1) "Dunia tempatnya kerja mba. Biar ndak bergantung lagi dengan orang tua. Mosok sudah tua rumah numpang, hidup minta makan minum sama orang tua. Malu. Sing penting ga ngrepoti orang lain”. (2) Ternyata bukan itu kokyang membuat seneng. Bukan kuantitasnya. Diusahakan tiap hari pulang, legrek sakit, malah ndak quality time. Masak ndak percaya sama pasangan. Serahkan Allah, biar kalau mau neko-neko tanggung jawab sama Allah. Sudah dibebaskan saja” (AI110515KK).

Dalam Tipe 2, dimulai dari sudut pandang bahwa dunia penting untuk diperjuangkan, mengharapkan sesuatu yang dicita-citakan dapat dicapai dengan baik. Di titik ini, seseorang masih berhubungan erat dengan mimpi dan cita-citanya. Sehingga pada saat mengalami permasalahan, masih dalam kondisi tidak seimbang. Usaha nyata yang dilakukan untuk mencapai cita-citanya cenderung menggebu-gebu untuk memenuhi keinginannya. Namun bukan berarti seseorang yang berada dalam kondisi seperti ini tidak bisa mencapai rasa Suwung. Suatu keadaan yang istimewa (dalam hal ini berupa cobaan tertentu) akan membawanya mencapai tahap kesadaran. Kesadaran ini akan membawanya menuju ke Alam Suwung.

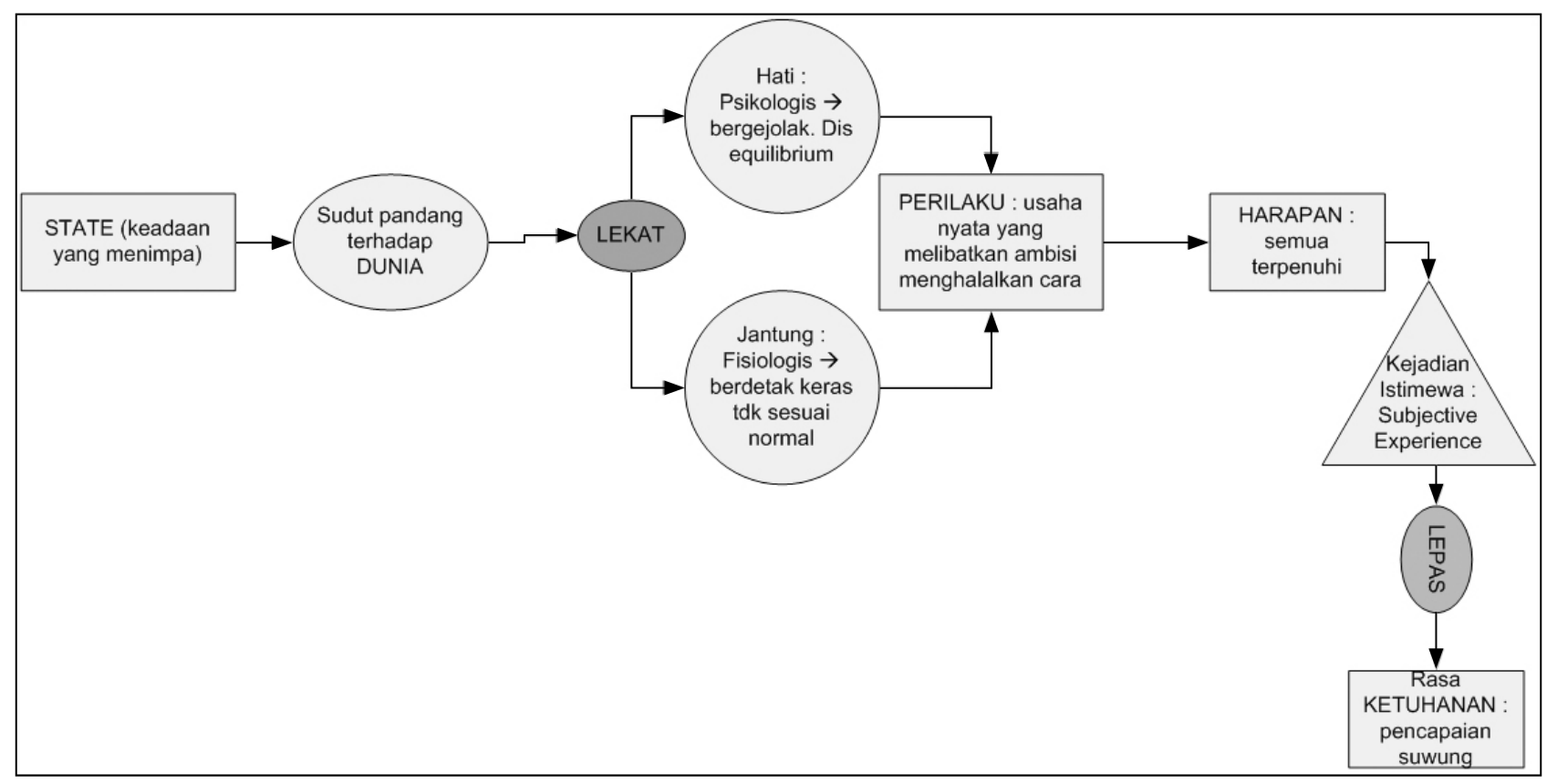

Bagan 4. Tipe 3 Alur Pencapaian Rasa Suwung

(1) "Dunia tempat kita membangun masa depan. Meletakkan pondasi kesejahteraan untuk anak cucu kita kelak. Jadi memang harus dicapai itu. Kalau lahir miskin itu ndak 
papa, tp kalau mati dalam kondisi miskin, itu patur ditanyakan kenapanya” (2) "Kalau kebutuhan semua ada ya. Tapi ada juga yang terluput. Kebayang kita hidup hanya berdua saja sementara keinginan saya membuat pondasi kesejahteraan untuk anak cucu saya? kan jadi ambyar ya... yang jalan bukan maunya kita ya pada akhirnya” (KK080515MM).

(1) "Dunia itu isinya ya dua sisi. Saya memaknainya ya dua sisi. Ya bisnis ya sosial, ya duniawi ya akhirat. Tapi perlu, kita harus memenangkan perang di dunia ini. Ga bisalah kalau urip segini-segini saja. Sepertinya hadistnya ndak gitu. Kaya kalau dermawan oke itu. Boleh. Makanya kaya itu prinsip ya. Biar bisa bantu sesame. " (2) kalo di bisnis, maen percaya di tipu orang sampe habis itu, itu sekarat lo. Bisa habis beneran. Kl ga kuat mentalnya, ya edan itu. Tapi ya mau edan mosok yo edan, koyok ga duwe Gusti Allah Ae. Percoyo mbak, onok sing ngatur" (JN090515SS).

Tipe 3, sama seperti tipe 2, masih memandang dunia membutuhkan usaha nyata untuk diperjuangkan dan dimenangkan. Namun ada satu titik saat harapannya juga telah terpenuhi, dan ada kejadian istimewa yang menimpanya. Hal tersebut dapat berupa penglihatan yang kurang mengenakkan baik tentang orang lain maupun lingkungan dan mampu menyentuh hidupnya, maka ia mampu terlepas dari sisi duniawinya. Pada akhirnya berhasil mencapai Suwung.

Hasil dari penelitian ini secara terpola menemukan dua kategori, yaitu mereka yang dari awal sudah memposisikan diri terpisah dan melepaskan diri dari hal-hal duniawi karena merasa dunia hanya sementara, kategori kedua masih memandang dunia adalah satu tempat yang membutuhkan perjuangan dan dimenangkan. Namun dari dua kategori itu menunjukkan bahwa dari ketiga kelompok subjek, baik yang kebutuhan dasarnya belum terpenuhi, terpenuhi dengan perjuangan, maupun yang sudah berhasil dengan mudah memenuhi kebutuhannya, mampu menerima suatu masalah dengan cara mengosongkan diri dan secara hakiki menerima Tuhan dalam kondisi apa pun. Keadaan Narimo dan syukur menjadi dasar penyelesaian masalah bagi seluruh subjek.

\section{Pola Penyelesaian Masalah}

Tahapan untuk mencapai Suwung pada masing-masing individu berbeda dan tidak terkategori berdasarkan klasifikasi subjek. Namun ketika dihadapkan pada suatu persoalan yang rumit dalam hidupnya, mereka terkategori sesuai dengan klasifikasinya.

Adapun kelompok subjek 1 yang masih belum bisa memenuhi kebutuhan dasarnya memiliki alur penyelesaian masalahnya dengan pola yang khas. Hal tersebut jelas terlihat dari hasil wawancara sebagai berikut:

"Sing penting dihadapi. Yo pasrah. Malah padang" (SS040515DD).

"Lo jangan salah. Ayem ati. Dengan pasrah jalan justru hadir. Itu tiba-tiba ada yang datang. Sebaiknya kamu gini-gini. Dipikir-pikir. Iya bener. Diikuti. Bisa!” (RR040515DI). 
"Endak Mbak. Akhirnya anak saya masuk rumah sakitjuga. Tetap tidak bisa pakek jamkes. Kesuwen. Takut ndak ketolong. Sing penting anak saya akhirnya sembuh. Ya Utang. Ndak papa. Pasti ada rejeki lain" (TT010515LL).

Kelompok ini berusaha dengan beberapa cara yang disukainya dan menyerahkan hasilnya kepada Tuhan dalam bentuk kepasrahan. Tiga subjek dalam kelompok ini menyatakan kepasrahannya. Ketika subjek sudah sampai pada titik pasrah, dia mampu berterima kasih kepada alam dan seluruh isinya. Apa pun yang menimpanya bukan lagi menjadi beban. Mereka yang sudah pasrah tidak tergantung apakah masalahnya berhasil diselesaikan atau tidak. Secara umum, bentuk penyelesaian masalahnya bisa digambarkan sebagai berikut:

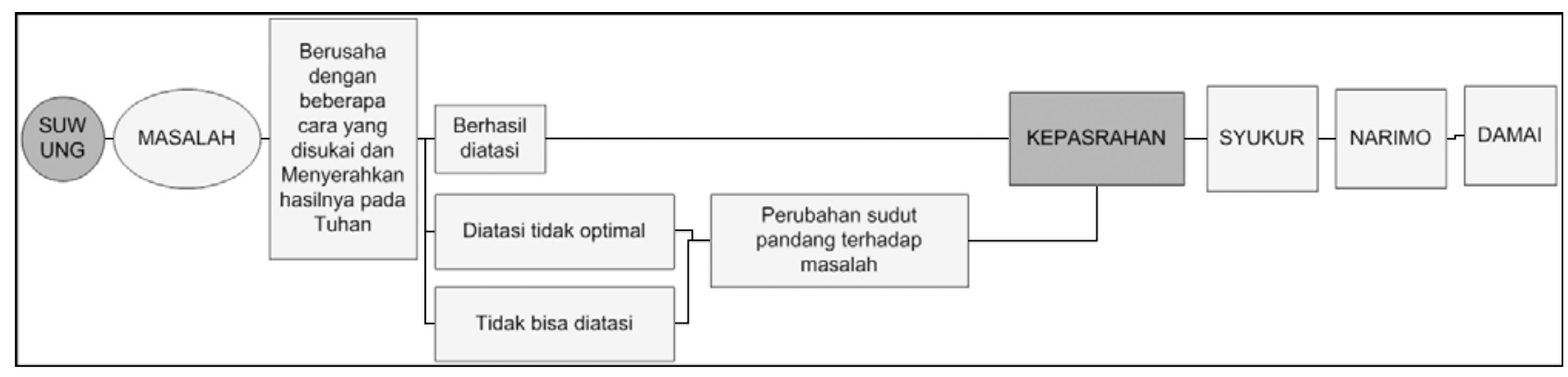

Bagan 5. Alur Penyelesaian Masalah Tipe 1

Adapun kelompok subjek 2 yang mampu memenuhi kebutuhannya namun masih perlu berjuang untuk mencapainya. Alur penyelesaian masalahnya juga tidak berbeda dan khas. Dari hasil wawancara menemukan persamaan pola, namun tahap penyelesaiannya berbeda.

"Gini ya. Awalnya mikir anak saya bisa masuk kedokteran. Meneruskan mimpi-mimpi keluarga. Milih jadi anak band. Ini klasik. Orang tua beda mau dengan anak. Mumet. Kita nasehati kayak dulu-dulu dia bisa manut. Ini sudah ndak bisa. Oke akhirnya sudah mau masuk mana, Sl kudu lulus. Dia mau. Alhamdulillah. Ya kompromi akhirnya. Alhamdulillah bisa” (AA090515KK).

"Sakit itu kan yang sakit pinginnya sembuh. Jadi berat kalau yang sakit tidak mau berobat. Ini maunya alternatif. Padahal sudah tidak bisa. Ngomong pelan-pelan sama bapak saya. Kami ingin yang terbaik. Beliau maunya bagaimana. masyaAllah.. ternyata ndak pingin merepotkan anak. Wes kita gini kumpulkan seluruh keluarga. Gimana enaknya. Oke semua sepakat mau bawa bapak ke dokter. Ngobrol dengan bapak, ora gelem. Kita ke alternatif Tapi Alhamdulillah bapak senang. Bahagia semua kumpul itu intinya. Ndak maksa. Tapi hati sama-sama tenang ndak papa" (AE100514KK).

"Win win solution akhirnya. Ndak papa saya sama istri saya tidak tinggal dalam satu kota. Intinya ada waktu ketemu. Bertemu setiap akhir pekan. Subhanallah, nikmate gusti Allah. Belum tentu lo yang ketemu tiap hari bisa seromantis kami ini hehehe”(AI110515KK). 
Kelompok ini berusaha melalukan cara yang sama ketika mengalami suatu permasalahan, Namun setelah tidak berhasil atau tidak optimal, ia akan mengubah langkah penyelesaian masalahnya. Baik ketika ia berhasil $100 \%$ mengatasi masalahnya maupun tidak sama sekali, pencapaian selanjutnya adalah menemukan jalan kompromi.

Jalan kompromi yang diambil karena kesadaran bahwa sebagian dari persoalan yang dihadapi justru tidak selesai ketika seseorang mempertahankan keinginan atau prinsip hidupnya secara mutlak. Dengan melakukan kompromi terhadap hal-hal yang tidak berhasil dicapainya, mereka akan mampu melangkah pada penyelesaian langkah baru. Ketika digambarkan dalam sebuah pola, akan terbentuk sebagai berikut:

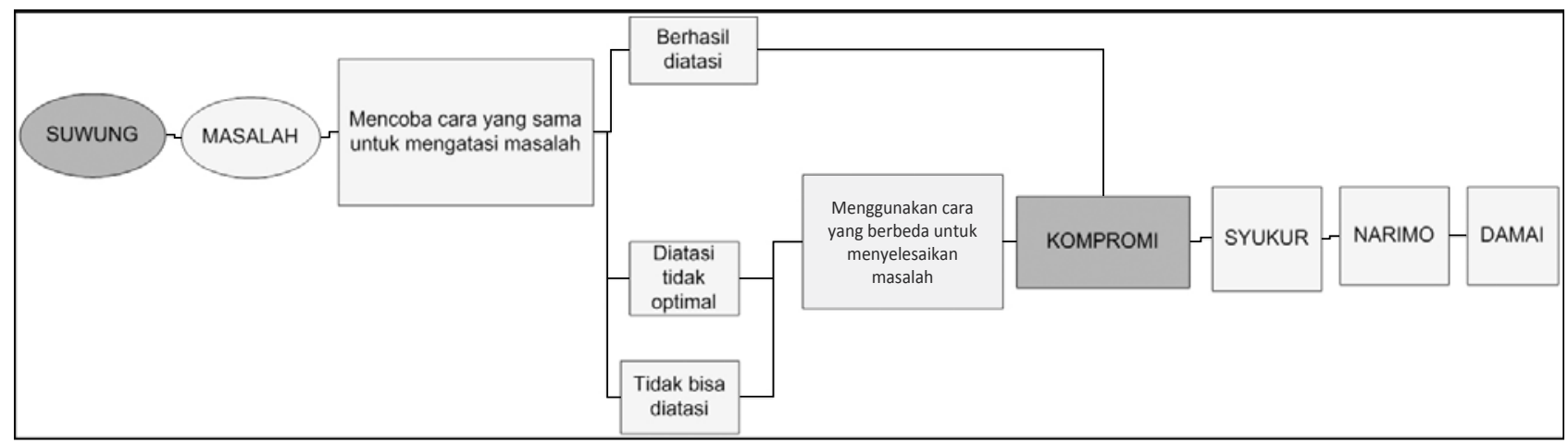

Bagan 6. Alur Penyelesaian Masalah Tipe 2

Kelompok ketiga adalah kelompok yang sudah memenuhi kebutuhan hidupnya. Golongan yang sudah mencapai kesejahteraan ini menghadapi masalah dengan mengusahakan berbagai cara yang dilakukan se-optimal mungkin. Usaha-usaha ini ditopang oleh fasilitas yang memadai dan cenderung memudahkan. Namun, ketika masalah yang dihadapi tidak kunjung selesai, maka mereka akan bertanya pada diri mereka sendiri dan melakukan pencarian makna.

"Ini saya anggap hikmah. Sudah usaha segini-gininya. Dibela-belain berobat sampai Singapur, sampai mana-mana. Pada akhirnya kita sadar. Hidup mati manusia bukan kita kan yang atur. Tarik nafas. Suwun gusti. Pun diparingi ibu hebat. Saatnya beliau pulang ngarsane gusti Allah” (KL090515SS).

"Apalagi, pingin memiliki anak sudah ke dokter mana-mana. Segala upaya. Akhirnya kita mikirnya, masih di suruh gusti Allah berduaan 10 tahun ini. Alhamdulillah masih langgeng, masih saling menyayangi. Ini justru anugerah. Dinikmati saja. ternyata asyik kok" (KK080515MM).

"Berat ya berat. Ditipu teman itu ga enak apalagi sampai begini. Habis lo uang keluarga. Wes ga duwe opo-opo. Sampai ke pengadilan. Ga ada bukti, ya kami kalah. Lihat sekarang. Saya, istri saya, anak saya malah makin dekat saling menyayangi. Kalau tidak ada kejadian itu, mungkin sudah kayak sinetron-sinetron itu. Keluarga gersang. Ini kami malah jadi dekatt sekali. Alhamdulillah." (JN090515SS). 
Usaha dalam menyelesaikan masalah yang akhirnya membawa mereka pada rasa kebersyukuran. Rasa bersyukur ini menyebabkan mereka memahami kehendak Tuhan dan menerimanya dengan sepenuh hati. Adapun bagan penyelesaian masalahnya, jika dibuat pola akan membentuk pola sebagai berikut:

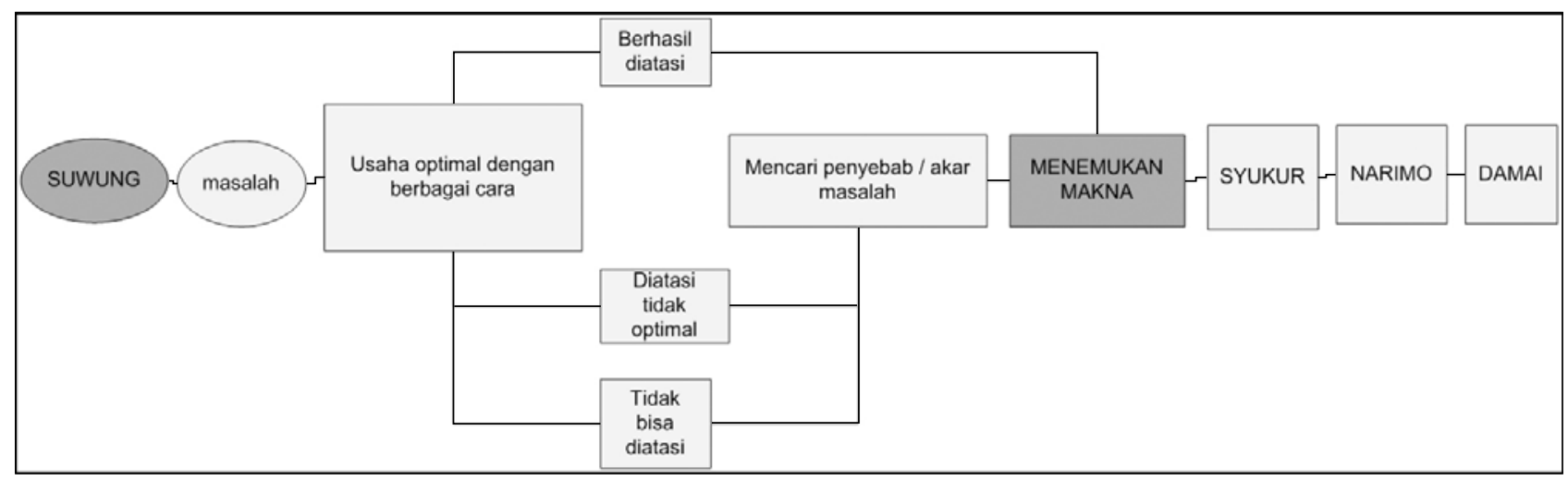

Bagan 7. Alur Penyelesaian Masalah Tipe 3

\section{DISKUSI}

Abraham Maslow mengatakan bahwa manusia memiliki tingkat kebutuhan hidup. Tingkatan tersebut berusaha dipenuhi sepanjang masa. Kebutuhan bersifat berjenjang, dari yang paling dasar sampai paling tinggi. Setiap orang pasti akan melalui tingkatan tersebut. Namun, hanya sedikit yang mampu mencapai tingkat tertinggi. Bagi mereka yang sudah mencapai aktualisasi dicirikan dengan beberapa hal, antara lain (1) persepsi yang lebih efisien dalam kenyataan. Mereka tidak dipengaruhi oleh kecemasan-kecemasan, prasangka-prasangka, atau optimisme dan pesimisme yang keliru (Hall, 1993); (2) memiliki otonomi pribadi (privasi). Mereka sepenuhnya percaya pada potensi-potensi yang mereka miliki. Selain itu, orang-orang yang mengaktualisasikan dirinya mereka memiliki kemampuan konsentrasi yang kuat dari kebanyakan orang (Koeswara: 1991); dan (3) memiliki kemandirian. Mereka cenderung menghindarkan diri dari penghormatan status, prestise, dan popularitas. Kepuasan yang berasal dari luar diri mereka anggap kurang penting ketimbang pertumbuhan diri, rasa humor yang tidak agresif, kerendahan hati dan menghargai orang lain, apresiasi yang segar, dan memiliki pengalaman spiritual (peak experience).

Konsep mengenai pemecahan masalah dalam referensi kognitif menekankan pada ditemukannya strategi efektif untuk pemecahan masalah. Matlin menjelaskan mengenai algoritma, yaitu prosedur yang menjamin kesuksesan ketika prosedur tersebut diikuti dengan benar. Matlin juga menjelaskan 
konsep heuristik, yaitu strategi mengabaikan alternatif yang tidak disukai dan menekankan pada alternatif yang disukai. Dalam pola pemecahan masalah di konsep Suwung ini, penekannya adalah dinamika psikologis orang yang sedang bermasalah tersebut. Sedangkan strategi yang diambil untuk pemecahan masalah bisa saja mengikuti prosedur tertentu (algoritma tertentu), atau memilih alternatif yang paling disukai (heuristik). Ketika seseorang sudah berada di level Suwung, maka akan muncul sikap syukur dan Narimo. Kondisi ini yang mengarahkan strategi pemecahan masalah seperti apa pun yang dipilihnya, ia mampu melaksanakannya secara jernih dan damai. Bahkan apabila sebuah strategi ternyata gagal dilakukan, ia masih tetap merasakan kedamaian dan tidak memunculkan respons negatif.

Dalam penelitian ini, sebelum memunculkan pola pemecahan masalah yang unik dan khas, 9 subjek mengalami pengalaman puncak secara spiritual, menemukan jalan yang mendamaikan ketika menghadapi suatu masalah meskipun 3 subjek ada di posisi belum terpenuhi basic needs-nya, 6 orang lainya juga belum berada dalam tahap aktualisasi diri. Ada hal lain selain pemenuhan kebutuhan yang semata duniawi yang ternyata mampu membawa seseorang meniti pencapaiannya. Rasa syukur dan Narimo yang menjadi dasar perasaan damai, yang dalam pencapaiannya tidak membutuhkan pemenuhan hierarki kebutuhan sesuai dengan konsep Maslow. Kondisi psikologis seperti ini yang mendukung efektivitas strategi pengambilan keputusan yang dipilihnya.

\section{SIMPULAN DAN SARAN}

\section{Simpulan}

Hasil dari penelitian ini menunjukkan bahwa dari ketiga kelompok subjek mampu menerima suatu masalah dengan cara mengosongkan diri dan secara hakiki menerima Tuhan dalam kondisi apa pun. Keadaan Narimo dan syukur menjadi dasar penyelesaian masalah bagi seluruh subjek. Dalam pencapaian Suwung, ada 3 tipe pencapaian yang pada masing-masing tipe tersebut tidak terkumpul berdasarkan kategori subjek penelitian. Tipe pertama adalah mereka memandang dunia terlepas dari dirinya. Tipe ini secara alami lebih mudah mencapai tahapan Suwung. Tipe kedua adalah mereka yang masih terikat dengan duniawi. Namun ketika mereka sudah melakukan usaha nyata untuk mencapai suatu tujuan, terdapat kejadian istimewa yang menjadikan mereka mengubah sudut pandangan mereka terhadap dunia, sehingga mengubah harapan hidup dan membawanya mencapai tahap Suwung. Tipe ketiga adalah tipe paling erat kelekatannya dengan dunia. Ia berperilaku untuk mencapai tujuannya, ia juga sudah membangun harapan yang sejalan dengan usahanya. Namun, karena adanya suatu 
kejadian istimewa yang menimpanya, ia akhirnya melepaskan diri dari pikiran duniawi dan mencapai Suwung. Selain temuan di atas, ada tiga perbedaan pola berpikir dari kelompok subjek penelitian dalam memecahkan suatu masalah. Pertama, manusia memecahkan masalah yang dihadapi dengan kepasrahan. Kedua, menyelesaikan masalah dengan cara berkompromi dengan fakta. Ketiga, menyelesaikan masalah melalui pencarian makna akan hidup.

Penelitian ini memberikan pemahaman bahwa konsep aktualisasi diri tentang kebutuhan pokok hidup yang disampaikan oleh Maslow tidak berlaku secara hierarki bagi masyarakat yang mempraktikkan paham Sufi. Pemaknaan mengenai Suwung tidak hanya bisa didapatkan oleh orang yang sudah memenuhi kebutuhan dasar semata, namun oleh mereka yang mampu dengan sadar mengendalikan dirinya sendiri. Meskipun demikian, terdapat pola yang sama dalam penyelesaian masalah pada subjek dalam kategori yang sama.

\section{Saran Teoretis}

Berikut adalah saran teoretis yang peneliti dapat berikan: (1) kajian mengenai konsep Suwung bisa dikembangkan dalam teori psikologi industri-organisasi, khususnya tentang kepemimpinan, mengingat kompetensi pemecahan masalah merupakan salah satu kompetensi dasar dalam teori kepemimpinan; dan (2) pola penyelesaian masalah berbasis agama atau kepercayaan bisa diteliti lagi pada populasi dan sampel yang lebih beragam, salah satunya dengan menekankan dinamika kelompok aliran tertentu, agama tertentu, atau kepercayaan tertentu dimungkinkan akan memberikan pola yang berbeda.

\section{Saran Praktis}

Berikut adalah saran praktis yang peneliti dapat berikan: (1) tahapan menuju Suwung bisa dicapai tanpa selalu diawali dengan critical experience yang bersifat wajib, sehingga tanpa menjadi bagian dari komunitas sufi pun masyarakat umum dapat menerapkan tahapannya agar bisa mencapai kondisi Suwung; dan (2) penerapan Syukur dan Narimo diaplikasikan dalam penyelesaian masalah sehari-hari sehingga menjadikan seseorang lebih jernih dalam memandang suatu masalah. 


\section{REFERENSI}

Achmad, S. W. (2008). Kitab ajaran ranggawarsita. Yogyakarta, Indonesia: Araska.

Ardianto, Elvinaro, \& Bambang, Q. (2007). Filsafat ilmu komunikasi. Bandung, Indonesia: Simbiosa Rekatama Media.

Davis, J. V. (2003). An overview of transpersonal psychology. The Humanistic Psychologist, 31(2-3), 6-21.

Endraswara, S. (2015). Agama Jawa. Yogyakarta, Indonesia: NARASI.

Hall, L.. (1993). Teori-teori Kepribadian. Jakarta, Indonesia: Rhineka Cipta.

Hamka. (2015). Tasawuf Modern. Jakarta, Indonesia: REPUBLIKA Press.

Ire. (2015). Masyarakat terbelenggu stres. Ditemu kembali dari http://print.kompas.com/ baca/2015/05/21/Masyarakat-TerbelengguStres

Koeswara, E. (1991) Teori-teori Kepribadian. Bandung, Indonesia: Eresco.

Lee, N. Y. L., \& Johnson-Laird, P. N. (2013). Strategic changes in problem solving. Journal of Cognitive Psychology, 25, 165-173. doi: 10.1080/20445911.2012.719021.

Maslow, A. H. (1964). Religion, values and peak-experiences. Columbus, Ohio: Ohio State University Press.

Matlin, M.W. (2005). Cognition (6th ed.). New York, NY: Wiley.

Ren, J., Huang, Z., Luo, J., Wei, G., Ying, X., Ding, Z., Wu, Y., \& Luo, F. (2011) Meditation promotes insightful problem-solving by keeping people in a mindful and alert conscious state. Sci China Life Sci, 54, 961-965. doi: 10.1007/s11427-011-4233-3.

West, R., \& Turner, L. H. (2008). Introducing communication theory: Analysis and application (3rd ed). Jakarta, Indonesia: Salemba Humanika.

Wibisono, G. (2015), 18 Polisi tewas di 2015, kasus bunuh diri terbanyak. Ditemu kembali pada http://news.okezone.com/read/2015/12/27/337/1275386/18-polisi-tewas-di-2015-kasus-bunuhdiri-terbanyak 